\title{
МЕХАНИЗМЫ ПСИХОФИЗИОЛОГИЧЕСКИХ МЕТОДОВ РЕГУЛЯЦИИ ФУНКЦИОНАЛЬНЫХ СОСТОЯНИЙ У СОТРУДНИКОВ ПОЛИЦИИ
}

УДК: 159.942 .2

\section{Кодлубовская Татьяна Борисовна}

Дочент, кандидат психологических наук, дочент кафедры, психологии, педагогики, медицинского и фармацевтического права, Национальная медицинская академия последипломного образования имени П. Л. Шупика, г. Киев ( Украина)

\begin{abstract}
Аннотация. В статье рассмотрены результаты исследования влияния комплекса индивидуально подобранных техник дыхания совместно с фитоарома средствами, акупрессурой и механизмы их воздействия на психофизиологические функииональные состояния сотрудников полиции. В группе, где проводилась исследования при индивидуальной форме проведения занятий, достоверно уменьшилось число лии, имеющихх признаки эмоциональной напряженности, агрессивности и тревожности. Повысились показатели состояний: самочувствия, активности и настроения. Подтверждена достоверность улучшения у них показателей резервов сердечно сосудистой системы и адаптационного потенциала.

Результаты исследования наглядно демонстрируют потенцииальные возможности индивидуально-подобранных дыхательных техник, фитоарома средств и акупрессуры, за короткое время (до 10 минут) позволяют нормализовать психофизиологический потенциал $u$ вегетативный баланс у сотрудников полиции.

Полученные результаты исследования доказывают важную роль подготовки сотрудников полищии в сфере психофизиологической саморегуляции функииональньх состояний после стресса для их нормализации $и$ профилактики посттравматических $u$ психосоматических нарушений.
\end{abstract}

Ключевъе слова: антистрессовая дыхательная фитоарома регуляция, акупрессура, самостоятельная психофизиологическая нормализация функичинальных состояний.

Постановка проблемы. Функциональные состояния - это особое психофизиологическое явление со своими закономерностями, которые заложены в структуру моделирующих функциональных систем и проявляются на субъективном психологическом, объективном физиологическом (биохимическом) и поведенческом уровнях человека.

Объективная сторона связана с физиологическими процессами в организме челове- 
ка и определяет особенности регуляции гомеостаза.

Субъективная сторона функционального состояния связана с психическими явлениями, которые относятся к личностным образованиям. Личностные механизмы регуляции состояний разнообразны, их организация соответствует иерархии организационной структуры личности.

Субъективная сторона функционального состояния является ведущей, так как в процессе адаптационных перестроек субъективные изменения намного опережают объективные. Поэтому функциональные состояния человека зависят в первую очередь от степени развития его духовных, моральных и волевых качеств, от общей эмоциональной направленности (преобладании определенных переживаний), личностных ложных бессознательных установок, которые блокируют (вытесняют) истинные чувства, способности к нейтрализации отрицательных эмоций, свойств его нервной системы, типа темперамента, скорости принятия адекватных решений и действий, особенно у специалистов экстремальных профессий к которым относятся сотрудники полиции.

Ведущая стратегия в регуляции адекватной реакции на стресс - это быстрое принятие решения в выборе оптимального способа поведения.

Основными составляющими этой стратегии являются: а) эмоционально-волевые и поведенческие усилия, с помощью которых человек может регулировать свое эмоциональное состояние и, тем самым, снизить аффективную тревогу при дистрессе.

б) быстрая оптимизация управления источниками, вызывающими дистресс для снижения интенсивности его проявления или устранения.

Недостаточное развитие адаптивных способностей к стрессу, неумение регулировать свое психофизиологическое состояние, в первую очередь включая морально-волевые основы личности, может стать источником серьезных негативных последствий не только для здоровья сотрудников полиции, их профессиональной деятельности, но и для жизни окружающих людей, особенно в экстремальных условиях. События на Киевском Майдане, в 2013-2014 годах и продолжающихся боевых действий на востоке Украины свидетельствуют о глубоком духовном, моральном кризисе не только в правоохранительной системе и других структур власти в Украине, но и в обществе в целом. Более подробный анализ причин неудовлетворительного состояния в подготовке сотрудников правоохранительной системы в Украине рассмотрен в статье «Анализ особенностей проявления признаков профессионального выгорания у сотрудников правоохранительных органов»[16].

Длительный профессиональный стресс может приводить к эмоциональному 
выгоранию, деформации личности и повышению текучести кадров. И если первые стадии хронического стресса характеризуются эмоциональными расстройствами, то на последующих стадиях стресс приводит к выраженному снижению иммунитета, дискоординации работы органов и систем, и, в результате - к органическим изменениям [5] .

В связи с вышеизложенным подготовка специалистов экстремальных профессий в области психофизиологической регуляции функциональных состояний является одной из первоочередных задач. Основой разработанного комплекса экспресс методов психофизиологической регуляции (саморегуляции) (КМПР) функцинальных состояний (ФС) является реализация психологических и физиологических закономерностей взаимовлияний коры головного мозга, внутренних органов и мышечной системы, используя способности человека к эмоциональному и чувственному восприятию мысленно представляемых образов и событий.

Например использование дыхательных методов связано с воздействием биологически обратной связи между частотой, глубиной, ритмом дыхания и эмоциональным состоянием.

Изменение в дыхании в зависимости от эмоционального состояния происходит бессознательно. Если же осознанно менять характер дыхания , то это в свою очередь повлияет на динамику эмоциональных реакций челове- ка.

\section{Анализ последних исследований и}

публикаций В научных исследованиях было установлено, что вдох повышает возбудимость некоторых центров головного мозга, а выдох понижает и оказывает активирующее действие, а с коротким вдохом и замедленным выдохом успокаивающее действие на организм человека [20].

Психофизиологический механизм действия метода аккупресуры - воздействие на биологические активне точки (БАТ) основан также на биологически обратной связи. Биологически активные вещества, которые находятся в зонах БАТ, служат гуморальным звеном рефлекторных дуг вегетативной нервной системы, регулирующей состояние организма [23].

В процессе выполнения акупресуры происходит регуляция эмоциональных и нервных состояний за счет нормализации силы, подвижности и устойчивости процессов возбуждения и торможения в коре головного мозга. От участков кожи, в которых находятся окончания нервных волокон, импульсы передаются к спинному мозгу, а от него, с помощью волокон парасимпатической и симпатической систем, к внутренним органам. Исследования Хирота и Янагия (Япония) доказали, что нервные импульсы могут двигаться в обоих направлениях - и от внутренних органов к коже и в обратном направлении [23].

Качественный эффект от дыхательных 
техник и акупрессуры значительно повышается при совместном их применении с натуральными эфирными маслами и аромафитобальзамами на их основе.

В 30-х годах прошлого столетия все прогрессивные клиники Европы обратились к методам ароматерапии для быстрого восстановления больных после травм, операций или при острых патологических состояниях. К 60м г.г. возникла новая база знаний о свойствах эфирных масел в рамках современных оздоровительных методик [18, 22]. В настоящее время продолжается изучение и разработка методик применения многогранных возможностей растительного мира не только в лечении различных заболеваний, но и в нормализации психофизиологических состояний людей [4,7,8, 9-15].

Цель и задачи проведенного исследования - оценка эффективности комплекса методов антистрессовой дыхательной фитоарома регуляции и акупрессуры для нормализации психофизиологических показателей функциональных состояний у сотрудников полиции.

Регуляция ФС у сотрудников полиции (далее респондентов) проводится после специальной психологической, физиологической диагностики и анализа полученных данных.

Данный метод разработан автором статьи. Работа была выполнена в Учебном центре последипломного образования Национальной академии внутренних дел г.Киеве на тренинговых занятиях «КоммуникацияСтресс-Безопасность». Выборку составили сотрудники правоохранительных органов различной специализации в возрасте от 25 до 40 лет со стажем работы от 2-х до 20 лет.

Форма проведения занятий - индивидуальная.

Методом случайной выборки были отобраны 2 группы:

$\Rightarrow \quad 1$-я группа в количестве 255 человек набиралась постепенно, при индивидуальной форме проведения занятий, с каждым из респондентов проводились 3 сеанса регуляции в течение 7 дней. Время проведения сеанса регуляции -10 минут +5 минут на подготовку.

$\Rightarrow \quad$ 2-я группа - контрольная, в количестве 270 человек, с которыми не проводились никакие мероприятия кроме диагностических.

Занятия проводились в одном и том же помещении в Психотренинговом комплексе Национальной академии внутренних дел г. Киев.

Уровни нервно-психической устойчивости, нейротизма, экстро-интроверсии, типа темперамента диагностировались по «тесту Айзенка ЕРІ», значения психологических показателей «Самочувствие», «Активность», «Настроение» у правоохранителей оценивали по «опроснику САН». Исследование уровня тревожности выполнялось по шкале реактивной и личностной тревожности Ч. Д. Спил- 
бергера-Ханина. Оценку эмоционального состояния агрессии проводили по проективному рисуночному тесту «Несуществующее животное» $[3,6,20]$.

Диагностика физиологических показателей функциональных состояний проводилась по методикам расчета вегетативного индекса Руфье и показателя адаптационного потенциала Р. М. Баевского [1,6].

Индивидуальный подбор техник дыхания, видов фитоарома средств и акупрессуры выполнялся с учетом их тонизирующих, расслабляющих, гармонизирующих свойств, а также в соответствии с полученными данными по методике «Вегетативный баланс» [6].

Для антистрессовой дыхательной фитоарома регуляции и акупрессуры применялись растительные эфирные масла и аромабальзамы на их основе, обладающие такими свойствами $[4,7,8-15]$ :

Тонизирующая группа: эфирные масла лимонника китайского, жасмина, сосны, аромабальзам «Прометей».

\section{Лимонник китайский (Shisandra} chinenis C Koch), Жасмин (Jasminum oxxicinale L), Сосна обыкновенная (Pinus sylvestris L): активизируют умственную деятельность, расширяют объем памяти, повышают работоспособность, увеличивают выносливость, нормализуют деятельность центральной нервной системы, мобилизуют психику, тонизируют, вызывают чувство оптимизма, уверенности, бодрости, нейтрализуют пессимизм, страхи и эмоциональную лабильность[7,18,22]. Аромабальзам «Прометей» (Prometey торговой марки «Aromasvit»): тонизирует психологическое и физиологическое состояние, повышает концентрацию внимания, мобилизует эмоционально-волевой потенциал при неуверенности и стрессе $[4,8,12,13]$.

Седативная группа: эфирные масла лаванды, валерианы, хмеля, аромабальзам «Релакс» (Relax).

Лаванда ( Lavandula officinalis Chai), Валериана (Valeriana officialis L), Хмель (Humulus Ynpulus L): оказывают успокаивающее, антистрессовое, антидепрессантное действие, устраняют эмоциональную лабильность, тревожные и истерические реакции, нормализуют сон, усиливают процессы торможения в коре головного мозга, нейтрализуют страхи и тревогу, устраняют раздражительность, истерические реакции, подавленное настроение, постстрессовые расстройства, раздражительность, подавленное настроение, постстрессовые расстройства $[18,22]$.

Аромабальзам «Релакс» (Relax торговой марки «Aromasvit»): $\quad$ нормализует деятельность вегетативной нервной системы, способствует мышечному расслаблению, эффективен при стрессовых, неврозных, депрессивных состояниях с повышенной возбудимостью, раздражительностью, бессонницей, ожиданием неудачи и панических состояниях $[4,8,12,14]$.

Гармонизирующая группа: эфирные 
масла апельсина, грейпфрута, лимона, аромабальзам «Риносепт-Арома».

Апельсин сладкий (Citrus silensis L. Osbeck), Грейnфрут (Citrus paradise Macxady), Лимон (Citrus Limon L): оказывают гармонизирующее и антидепрессантное влияние, нормализуют деятельность вегетативной нервной системы и вестибулярного аппарата, нейтрализуют страхи и тревогу устраняют депрессию, меланхолию, подавленное настроение, переутомление; эффективны при неврозе и депрессии [7,18,22].

\section{Аромабальзам}

«Риносепт-

Арома» (Rinosept-Aroma торговой марки «Aromasvit») оказывает антистрессовое, иммуномодулирующее действие, гармонизирует психофизиологическое состояние $[4,8,12$, $15]$.

Методика заключалась в том, что инструктор-психолог объясняет технику разных видов дыхания, акупрессуры и помогает в самостоятельном индивидуальном подборе респондентами фитоарома средств, с учетом полученных результатов по диагностике состояния вегетативной нервной системы, тесту «Вегетативный баланс» (симпатикотония, парасимпатикотония, эутония) и личностному предпочтению того или иного запаха в рамках одной из групп (тонизирующей, успокаивающей, гармонизирующей). Так выбиралось одно из фитоарома средств и вида акупрессуры успокаивающего ряда при преобладании симпатических влияний, из тонизирующего ряда при преобладании парасимпатических влияний и из гармонизирующего ряда фитоарома средств и акупрессуры при эутонии. Самостоятельно подобранные эфирные масла наносились на салфетку (которую размещали на близком расстоянии к носу) и вдыхались соответствующими видами дыхания: при преобладании парасимпатических влияний тонизирующим способом, при преобладании симпатических влияний седирующим и гармонизирующим способом при эутонии $[9,10,11]$.

$$
\text { Аромабальзамы }
$$

«Прометей», «Релакс», «Риносепт-Арома» наносились по 1 капле на точки пульса на руках, точки за ушами, и между краем верхней губы и носом ( привычные точки нанесения духов). Дыхание выполнялось аналогично дыханию с эфирными маслами. [7, 9, 10, 11, 13-15]. Одновременно осуществлялась акупрессура БАТ на руках для тонизации; для седации; для гармонизации. Время воздействия было подобрано эмпирическим путем с целью определения оптимальной длительности влияния на психофизиологическое состояние респондентов и составляло 10 минут [7, 12].

Диагностику интенсивности проявлений функциональных состояний по показателям психологического (субъективного) уровня: самочувствия, активности, настроения, тревожности, агрессивности исследовали по методикам: САН, Ч. Д. Спилбергера-Ханина, рисунок «Несуществующего животного». По показателям физиологического (объек- 
тивного) уровня выполняли по замерам частоты дыхания, частоты сердечных сокращений (пульса), артериального давления (для расчета индекса Руфье и показателя адаптационного потенциала Баевского Р. М.). Все вышеназванные методики проводились дважды - до регуляции и после. Один раз проводилась методика Айзенка для определения уровня нервнопсихической устойчивости, нейротизма, психотизма и методика «Вегетативный баланс» для индивидуального подбора способов дыхания, видов акупрессуры и фитоарома средств с учетом полученных данных показателей симпатических, парасимпатических влияний, эутонии ВНС.

Статистическая обработка полученных результатов выполнялось с помощью пакета стандартных статистических программ «Stat Soft Statistica». Для определения достоверно- сти изменения психологических и физиологических показателей функциональных состояний респодентов до и после проведения комплекса антистрессовой дыхательной фитоаромарегуляции и аккупрессуры применялся tкритерий Стьюдента (СТ), критерий Знаков (К3), и методы выборочного исследования У.Кокрена.[17,19].

\section{Результаты.}

Полученные данные исследования показателей самочувствия, активности и настроения по методике САН представлены в таблице № 1.

Анализ результатов, полученных после воздействия антистрессовой дыхательной фитоарома регуляциии и акупрессуры, показал, что у $80 \%$ респондентов улучшилось самочувствие при индивидуальной форме проведения занятий и, практически, не изменилась в

Таблийа № 1 .

Динамика самочувствия, активности, настроения респондентов после антистрессовой дыхательной фитоарома регуляции и акупрессуры

\begin{tabular}{|c|c|c|c|c|c|c|c|c|c|}
\hline \multirow{4}{*}{$\begin{array}{c}\text { Категория респон- } \\
\text { дентов } \\
\text { Форма } \\
\text { проведения } \\
\text { занятий } \\
\text { числен- } \\
\text { ность } \\
\text { группы }\end{array}$} & \multicolumn{9}{|c|}{ МЕТОДИКА САН } \\
\hline & \multicolumn{3}{|c|}{ Самочувствие } & \multicolumn{3}{|c|}{ Активность } & \multicolumn{3}{|c|}{ Настроение } \\
\hline & \multirow{2}{*}{$\begin{array}{c}\text { До } \\
\text { средн } \\
\text { знач. } \\
\text { показ. }\end{array}$} & \multicolumn{2}{|c|}{ После } & \multirow{2}{*}{$\begin{array}{c}\text { До } \\
\text { средн } \\
\text { знач. } \\
\text { показ. }\end{array}$} & \multicolumn{2}{|c|}{ После } & \multirow{2}{*}{$\begin{array}{c}\text { До } \\
\text { средн. } \\
\text { знач. } \\
\text { показ. }\end{array}$} & \multicolumn{2}{|c|}{ После } \\
\hline & & $\begin{array}{c}\text { средн } \\
\text { знач. } \\
\text { показ. }\end{array}$ & $\begin{array}{c}\text { улучш. } \\
\text { показ. } \\
\text { \% от } \\
\text { общ. } \\
\text { числ. }\end{array}$ & & $\begin{array}{c}\text { средн } \\
\text { знач. } \\
\text { показ. }\end{array}$ & $\begin{array}{c}\text { улучш. } \\
\text { показ. } \\
\text { \% от } \\
\text { общ. } \\
\text { числ. }\end{array}$ & & $\begin{array}{c}\text { средн } \\
\text { знач. } \\
\text { показ. }\end{array}$ & $\begin{array}{c}\text { улучш. } \\
\text { показ. } \\
\text { \% от } \\
\text { общ. } \\
\text { числ. }\end{array}$ \\
\hline $\begin{array}{l}\text { Группа №1 } \\
\text { индивидуальная } \\
\mathrm{n}=255\end{array}$ & 6,1 & 7,3 & 80,1 & 5,8 & 6,7 & 77,3 & 6,4 & 7,7 & 81,5 \\
\hline $\begin{array}{l}\text { Группа №2 } \\
\text { Контрольная } \\
\mathrm{n}=270\end{array}$ & 6,2 & 6,3 & - & 5,8 & 5,9 & - & 6,4 & 6,6 & - \\
\hline
\end{tabular}

Примечание: * достоверность различий $p=0,05$ КЗ по сравнению с показателями до регулящии. 
контрольной группе.

В психологическом плане существенным представляется характеристика активности состояния, как качество, которое базируется на потребностях и интересах личности и существует как внутренняя готовность к действию [2]. После проведения регуляции готовность к действию выросла у 77 \% респондентов при индивидуальной форме проведения занятий и не изменилась в контрольной группе.

Настроение - это феномен, относящийся к душевному бытию личности. Физическое здоровье и настроение взаимосвязаны и обусловливают друг друга. Повышенное, бодрое, жизнерадостное настроение приводит к повышению жизненного тонуса и психологической устойчивости, защищает от болезней и создает базис для сохранения здоровья. Настроение теснейшим образом связано с тем, как складываются для личности жизненно важные отношения с окружающими, с ходом ее собственной деятельности. Существенным для настроения является не только сам по себе объективный ход событий, но и то, как человек расценивает происходящее и относится к нему [21].

По результатам тестирования по тесту $\mathrm{CAH,} \mathrm{после} \mathrm{проведения} \mathrm{регуляции} \mathrm{настроение}$ улучшилось у $81 \%$ респондентов при индивидуальной форме проведения занятий и, практически, не изменилось в контрольной группе. Особенно сильное влияние на настроение оказывает эмоциональная составляющая. Срав- нение эмоционального состояния до и после проведения регуляции осуществлялось по проективной методике рисунок «Несуществующее животное». [3].

С целью проведения оптимального анализа динамики эмоциональных состояний респондентов по рисунку, а также перехода от их качественной характеристики к количественной оценке, был выбран ряд показателей для учета изменения эмоционального состояния у респондентов под влиянием антистрессовой дыхательной фитоаромарегуляции и акупрессуры:

Изменение размера рисунка: (+) увеличение - положительная динамика эмоционального состояния; (-) уменьшение - отрицательная динамика эмоционального состояния; (0) эмоциональное состояние не изменилось;

Изменение положения рисунка на лиcme: (+) вправо, вверх - положительная динамика; (-) влево вниз - отрицательная динамика; (0) без изменений;

Элементы рисунка: (+) уменьшение или отсутствие острых углов в рисунке (клыков, зубов) - положительная динамика; (-) их наличие - отрицательная динамика; (0) без изменений.

По числу каждого из этих показателей, определили изменения эмоционального состояния по каждому респонденту и в целом по группам. Принимая общее число рисунков в каждой группе за 100\%, подсчитали динами- 
ку изменения рисунков по перечисленным показателям. В итоге были получены следующие результаты: изменение эмоциональных состояний с положительной направленностью при индивидуальной форме занятий зафиксировано у $78 \%$ респондентов, а в контрольной группе изменения не наблюдались. Аналогично исследование состояния тревожности по шкалам Ч. Д. Спилбергера-Ханина у сотрудников полиции под влиянием показало, что значение показателей реактивной тревожности снизилось у $77 \%$ респондентов $(\mathrm{P}=0,01$ К3), а личностной тревожности у $75 \%$ респондентов ( $\mathrm{P}=0,01$ КЗ). Методика расчета вегетативного индекса Руфье по формуле (IP=ЧССхАТсист. : 100), позволила обьективно оценить эффективность влияния антистрессовой дыхательной фитоаромарегуляции и акупрессуры на уровень резервов и экономизацию функции сердечно-сосудистой системы респондентов с учетом следующих критериев (в баллах): низкий -111, ниже среднего 95110 , средний 85-94, выше среднего 70-84, высокий $<69$ [6]. Динамика показателя резервов сердечно-сосудистой системы представлена в таблице № 2.

После регуляции у 76\% респондентов подтверждена достоверность улучшения показателей состояния резервов сердечнососудистой системы при индивидуальной форме проведения занятий, в контрольной группе изменения не наблюдались.

Стрессоустойчивость человека можно рассматривать как степень выраженности адаптационных (приспособительных) реакций, обусловленных развитием функциональных резервов организма. Для оценки адаптационного потенциала респондентов по методике Р. М. Баевского измерялся уровень артериального давления, частоты сердечных соТаблициа № 2.

Динамика психологического и физиологического состояния респондентов после антистрессовой дыхательной фитоарома регуляции и акупрессуры

\begin{tabular}{|c|c|c|c|c|c|c|}
\hline \multirow{3}{*}{$\begin{array}{c}\text { Категория респонден- } \\
\text { тов. } \\
\text { Форма } \\
\text { проведения } \\
\text { занятий, } \\
\text { числен- } \\
\text { ность } \\
\text { группы }\end{array}$} & \multicolumn{3}{|c|}{ Показатели вегетативного индекса Руфье } & \multicolumn{3}{|c|}{$\begin{array}{c}\text { Показатеоголи адаптационного потенциа- } \\
\text { ла по Р. М. Баевскому }\end{array}$} \\
\hline & До & \multicolumn{2}{|c|}{ После } & До & \multicolumn{2}{|c|}{ После } \\
\hline & $\begin{array}{c}\text { среднее } \\
\text { знач. } \\
\text { показа- } \\
\text { телей }\end{array}$ & $\begin{array}{c}\text { среднее } \\
\text { знач. } \\
\text { показа- } \\
\text { телей }\end{array}$ & $\begin{array}{c}\text { улучшен. } \\
\text { показат. } \\
\text { \% от общей } \\
\text { числ. }\end{array}$ & $\begin{array}{c}\text { среднее } \\
\text { знач. } \\
\text { показа- } \\
\text { телей }\end{array}$ & $\begin{array}{c}\text { среднее } \\
\text { знач. } \\
\text { показа- } \\
\text { телей }\end{array}$ & $\begin{array}{c}\text { улучшен. } \\
\text { показат. } \\
\text { \% от общей } \\
\text { числ. }\end{array}$ \\
\hline $\begin{array}{c}\text { Группа №1 } \\
\text { индивидуальная } \\
\text { n=255 }\end{array}$ & 98,0 & 90,9 & 76,5 & 2,9 & 2,1 & 78,4 \\
\hline $\begin{array}{c}\text { Группа №2 } \\
\text { контрольная } \\
\text { n=270 }\end{array}$ & 98,2 & 98,1 & - & 2,9 & 2,8 & - \\
\hline
\end{tabular}

Примечание: * достоверность различий при р<0,05 СТ по сравнению с показателями до регуляции. 
кращений, а также регистрировался возраст, масса тела и рост каждого респондента. Полученные результаты, рассчитанные по формуле: $\quad($ АП $=0,011 \times$ ЧСС+0,014xАДсист. $+0,008 x$ АДдиаст.+0,014xB+0,009xm-0,009xh-0,27), интерпретировались с учетом следующих характеристик значений адаптационного потенциала (в баллах) [1]:

менее 2,1 - удовлетворительная адаптация, высокие или достаточные функциональные возможности организма ,а также адаптации, достаточные функциональные возможности обеспечиваются за счет функциональных резервов;

3,21 - 4,3 - неудовлетворительная адаптация, снижение функциональных возможностей организма;

больще 4,3 - срыв адаптации, резкое снижение функциональных возможностей организма.

Динамика адаптационного потенциала до и после регуляции представлена в таблице № 2. После регуляции у $78 \%$ респондентов подтверждена достоверность улучшения показателей адаптационного потенциала в группах с индивидуальной формой проведения занятий (сохранение динамики показателей через 2 недели). В контрольной группе изменения не наблюдались.

Данный метод индивидуального подбора способов дыхания, видов акупрессуры и фитоарома средств в соответствии с показателями вегетативного баланса, позволяет в тече- нии 10 минут достичь гармоничного эмоционального, психологического и физиологического состояния.

Кроме того, индивидуальный подбор фитоарома средств позволяет получить более быстрый и пролонгированный эффект [7]. Это объясняется тем, что запахи натуральных эфирных масел и, особенно их композиции, способны оптимизировать психоэмоциональное и физиологическое состояние человека. Это заметно проявляется при переутомлении (астении), при напряжении (возбуждении, перевозбуждении). Применение перечисленных методов позволяет переводить функциональное состояние из непродуктивного режима в продуктивный, за счет моделирующего влияния запаха натуральных эфирных масел на регуляторные системы мозга [7, 9-15].

Особенности влияния натуральных эфирных масел и их композиций на организм человека заключаются в следующем.

1) Обонятельная луковица анатомически и физиологически связана со структурами лимбической системы мозга (гиппокамп, гипофиз, гипоталамус, миндалевидное тело), ответственной за важнейшие психофизиологические функции живых организмов[7]. 2) Существует три пути воздействия ароматических веществ на организм человека: нервно-рефлекторный, ассоциативный и гуморальный. Последний осуществляется благодаря обильной сети капилляров в слизистой оболочке носа, последующих дыхательных путей 
и альвеол легких. Таким образом, обеспечивается быстрое всасывание ароматических веществ в кровь[7].

3) Научно доказано, что действие веществ, поступающих в организм человека через дыхательные пути, проявляется в 20 раз быстрее и сильнее по сравнению с приемом их во внутрь в виде настоев и отваров [7].

4) Попадая в организм человека, ароматические вещества натуральных эфирных масел способны изменять его психофизиологические состояния: эмоции, внимание, память, скорость принятия решения, ритм дыхания, сердцебиение, мышечный и сосудистый тонус, сердечный выброс и уровень биохимических показателей [7].

5) В коре головного мозга обонятельные ощущения вызывают определенные ассоциации, - возбуждающие, успокаивающие или уравновешивающие (гармонизирующие) действие вегетативной и центральной нервной системы, связанной, в свою очередь, с гармональной сферой. Поэтому, при вдыхании запахов тонизирующего ряда эфирных масел лимона, жасмина, сосны, в организме человека увеличивается влияние симпатического отдела вегетативной нервной системы и выделяется гормон эндорфин. В этом случае ощущается прилив энергии, легкая эйфория и ощущение радости. При вдыхании успокаивающих запахов (лаванды, валерианы, хмеля) увеличивается влияние парасимпатического отдела вегетативной нервной системы и выделяется гормон - серотонин, что оказывает успокаивающий и расслабляющий эффект [7].

6) Механизмы действия дыхательной фитоарома регуляции связаны с реакцией рецепторов луковицы носа, которая передается на структуры лимбической системы мозга и через включение центральной и вегетативной нервной системы осуществляется регуляция психофизиологических процессов в организме человека [7].

Применение композиции в составе нескольких эфирных масел в аромабальзамах «Прометей», «Релакс» и «Риносепт-Арома» позволяет качественно усилить эффект при антистрессовой регуляции и быстро нормализовать у респондентов психофизиологические показатели функциональных состояний [7,13-15].

Выводы. Проведенные исследования показали:

1. В настоящее время недостаточно исследованы психофизиологические возможности сотрудников полиции для оптимизации режимов их активной работы и восстановления после стресса.

2. Успешность психологической подготовки полиции к деятельности в стрессовых и экстремальных условиях заключается в овладении ими методами саморегуляции с мобилизацией собственных резервов психофизиологической активности.

3. Для психофизиологической регуляции сотрудникам полиции предложен ком- 
плексный метод антистрессовой дыхательной фитоарома регуляции и акупрессуры, который позволяет быстро и эффективно достичь нормализации функционального состояния организма и эмоционального комфорта.

4. Индивидуально подобранные техники тонизирующего, расслабляющего и гармонизирующего дыхания, в комплексе с фитоарома средствами и акупрессурой, дают стабильный эффект в регуляции психофизиологического состояния, улучшают показатели функционирования сердечнососудистой системы ,адаптационного потенциала и нормализуют вегетативный баланс.

5. Комплексный метод антистрессовой дыхательной фитоарома регуляции и акупрессуры прост, доступен, создает благоприятные условия для восстановления нормальных психофизиологических показателей функциональных состояний в сжатые сроки (10 минут) и может применяться для специалистов работающих в экстремальных условиях, а также как восстанавливающий метод после стресса для широкого круга людей.

6. Изложенный в статье комплексный метод регуляции функциональных состояний сотрудников полиции основан на психофизиологических механизмах индивидуального личностного подхода (ИЛП), психологической и биологической обратной связи (БОС). Технология применения данного метода состоит из этапов: экспрес-диагностики (самодиагностики), экспресс-анализа (само- анализа) полученной информации о психофизиологических показателей функциональных состояний, индивидуального подбора методов регуляции, выполнения техник регуляции (саморегуляции) и контрольной диагностики психофизиологических показателей после применения комплекса регулирующих методик.

Результаты применения КМПР статистически достоверны. Метод имеет ряд патентов, подтвержден актами внедрения.

Перспективным является дальнейшее исследование психофизиологических возможностей сотрудников полиции для оптимизации режимов их активной работы и восстановления после стресса.

\section{Перелік використаних джерел:}

1. Баевский Р. М. Прогнозирование состояний на грани нормы и патологии. - М.: Медицина,1979.-295 с.

2. Бехтерев В. Ф. Активность личности: психолого педагогические аспекты воспитания в современных условиях :Учеб. пособие.- Красноярск, 1996.-140 с.

3. Бурлачук Л. $Ф$. Словарь-справочник по психодиагностике.-СПб.: Питер, 2008.-688 с.

4. Висновок державної санітарно-гігієнічної експертизи на «засоби гігієнічні, ароматичні, косметичні» MO3 України № 5 - 10 / 20324 - Київ. 2002._-3 с.

5. Кодлубовська Т. Б. Аналіз стресу людини у сучасних екологічних умовах // Актуальні проблеми психології. Екологічна психологія. Вип.14. Інститут психології ім. Г.С.Костюка АПН України. К, 2008. - с.118-122.

6. Комплексна методика визначення психофізіологічного стану військовослужбовців на етапі професійного відбору для участі у міжнародних миротворчих опера- 
ціях ННДЦОТ і ВБ України, К, 2005. - 123 с.

7. Кодлубовская Т. Б. Особенности проявления эмоциональных состояний человека под влиянием запаха эфирных масел / Дис. канд. психол. наук. - К.: КНАУ им.Тараса Шевченко,2000.-295 с.

8. Кодлубовская Т. Б./Технические условия ТУ У 24-6 19128234.001-2002 на Средства ароматические гигиенические косметические. К. - 2002.- 16 с.

9. Кодлубовська Т. Б. Патент№ 22665. Бюл.№5 від 25.04.2007.Спосіб тонізуючого дихання для психофізіологічної реабілітації. Держ. Патент України.К, 2007-4c. 10. Кодлубовська Т. Б. Патент №22666. Бюл.№5 від 25.04.2007.Спосіб релаксуючого дихання для психофізіологічної реабілітації. Держ. Патент України. К,$2008-4 \mathrm{c}$.

11. Кодлубовська T. Б. Патент №22687.Бюл.№5 від 25.04.2007.Спосіб гармонізуючого дихання для психофізіологічної реабілітації. К, 2007- 4c.

12. Кодлубовська Т. Б. Особливості застосування аромапсихопунктури для впливу на організм пацієнта у центрах психологічної реабілітації: // Збірник наукових праць співробітників Київської медичної академії післядипломної освіти ім. П. Л. Шупика. Випуск 14, книга 1.-К.,2005.- c. 500-504.

13. Кодлубовська Т. Б. Патент на корисну модель № 3225712.05 .08 р. Бюл. №9. Спосіб мобілізації психоемоційного, та фізіологічного стану пацієнта. К., 2008.$4 \mathrm{c}$.

14. Кодлубовська Т. Б. Патент на корисну модель № 3225812.05 .08 р. Бюл. №9. Спосіб профілактики і корекції психоневротичних розладів пацієнта.К., -4 с.

15. Кодлубовська T. Б. Патент на корисну модель № 31238, 25.03.08 р. Бюл. № 6. Спосіб відновлення психофізіологічного стану пацієнта. К., 2008. - 4 с.

16. Кодлубовская Т. Б. Анализ особенностей проявления признаков профессионального выгорания у сотрудников правоохранительных органов. Електр. Наукометричний фаховий журнал «Технології розвитку інтелекту» т.2 № 5 (16) (2017).-20 c.

17. Кокрен У. Методы выборочного исследования.-М.:
Статистика, 1976.- 440 с.

18. Нагорная Н. В. Аромотерапия в педиатрии. Записки практического врача./ Usti nad Labem1998. - 288 с.

19. Поляков Л. Е. Статистические методы исследования в медицине и здравоохранении. Л., 1971-576 с.

20. Розов В. И. Управление стрессом в оперативнорозыскной деятельности./ К.: - КНП, 2006. -265 с.

21. Рубинштейн С. Л. Основы общей психологии. СПб.:Питер, 2002.- 720 с.

22. Солдатченко С. С., Белоусов Е. В., Пидаев А. В. Ароматерапия для каждой семьи .- К.: Здоровье., 2001. $-475 \mathrm{c}$.

23. Yanagiya S. Familiengeheime Eintich - Akupunktur.Ulm - Donau, 1956-79 p.

\section{References (Transliteration):}

1. Baevskiy R. M. Prognozirovanie sostoyaniy na grani normyi i patologii. - M.: Meditsina, 1979.-295s.

2. Behterev V. F.Aktivnost lichnosti: psihologo - pedagogicheskie aspektyi vospitaniya $\mathrm{V}$ sovremennyih usloviyah :Ucheb. posobie.- Krasnoyarsk, 1996.-140s.

3. Burlachuk L. F. Slovar-spravochnik po psihodiagnostike.-SPb.: Piter, 2008.-688s.

4. Visnovok derzhavnoYi sanItarno-gIgIEnIchnoYi ekspertizi na «zasobi gIgIEnIchnI, aromatichnI, kosmetichnI» MOZ UkraYini \#5-10/20324 -KiYiv.2002.-3s

5. Kodlubovska T. B. AnalIz stresu lyudini u suchasnih ekologIchnih umovah//AktualnI problemi psihologIYi. EkologIchna psihologIya.Vip.14. Institut psihologIYi Im. G.S.Kostyuka APN UkraYini. K, 2008. -s.118-122.

6. Kompleksna metodika viznachennya psihofIzIologIchnogo stanu vIyskovosluzhbovtsIv na etapI profesIynogo vIdboru dlya uchastI u mIzhnarodnih mirotvorchih operatsIyah NNDTsOT I VB UkraYini, K, 2005.-123s.

7. Kodlubovskaya T. B. Osobennosti proyavleniya emotsionalnyih sostoyaniy cheloveka pod vliyaniem zapaha efirnyih masel / Dis. kand. psihol. nauk.- K.: KNAU im. Tarasa Shevchenko,2000.-295 s.

8. Kodlubovskaya T. B./Tehnicheskie usloviya TU U 24-6- 
19128234.001- 2002 na Sredstva aromaticheskie gigienicheskie kosmeticheskie.K.-2002.-16s.

9. Kodlubovska T. B. Patent\# 22665. Byul.\#5 vId 25.04.2007.SposIb tonIzuyuchogo dihannya dlya psihofIzIologIchnoYi reabIlItatsIYi. Derzh. Patent UkraYini.K, 2007-4s.

10. Kodlubovska T. B. Patent \#22666. Byul.\#5 vId 25.04.2007.SposIb relaksuyuchogo dihannya dlya psihofIzIologIchnoYi reabIlItatsIYi. Derzh. patent UkraYini. $\mathrm{K},-2008-4 \mathrm{~s}$.

11. Kodlubovska T. B. Patent \#22687.Byul.\#5 vId 25.04.2007. SposIb garmonIzuyuchogo dihannya dlya psihofIzIologIchnoYi reabIlItatsIYi. K, 2007- 4s.

12. Kodlubovska T. B. OsoblivostI zastosuvannya aromapsihopunkturi dlya vplivu na organIzm patsIEnta $\mathrm{u}$ tsentrah psihologIchnoYi reabIlItatsIYi: //ZbIrnik naukovih prats spIvrobItnikIv KiYivskoYi medichnoYi akademIYi pIslyadiplomnoYi osvIti Im.P.L.Shupika.Vipusk 14, kniga 1.-K.,2005.- s. 500-504.

13. Kodlubovska T. B. Patent na korisnu model \# 32257 12.05.08 r. Byul. \#9. SposIb mobIlIzatsIYi psihoemotsIynogo, ta fIzIologIchnogo stanu patsIEnta. K.,2008.$4 s$.

14. Kodlubovska T. B. Patent na korisnu model \# 32258 12.05.08 r. Byul. \#9. SposIb profIlaktiki I korektsIYi psihonevrotichnih rozladIv patsIEnta.K., $-4 \mathrm{~s}$.

15. Kodlubovska T. B. Patent na korisnu model \# 31238 25.03.08 r. Byul. \# 6. SposIb vIdnovlennya psihofIzIologIchnogo stanu patsIEnta. K.,2008.- 4s.

16. Kodlubovskaya T. B. Analiz osobennostey proyavleniya priznakov professionalnogo vyigoraniya $\mathrm{u}$ sotrudnikov pravoohranitelnyih organov. Elektr.Naukometrichniy fahoviy zhurnal «TehnologIYi rozvitku Intelektu» t.2 \# 5 (16) (2017).-20s.

17. Kokren U. Metodyi vyiborochnogo issledovaniya.-M.: Statistika, 1976.- 440s.

18. Nagornaya N. V. Aromoterapiya v pediatrii. Zapiski prakticheskogo vracha./ Usti nad Labem1998.-288c.
19. Polyakov L. E. Statisticheskie metodyi issledovaniya v meditsine i zdravoohranenii. L., 1971-576 s.

20. Rozov V. I. Upravlenie stressom $\mathrm{v}$ operativnorozyisknoy deyatelnosti./ K.: - KNP, 2006. -265 s.

21. Rubinshteyn S. L. Osnovyi obschey psihologii. SPb.:Piter, 2002.- $720 \mathrm{~s}$.

22. Soldatchenko S. S., Belousov E.V., Pidaev A.V. Aromaterapiya dlya kazhdoy semi . K.: Zdorove., 2001. - 475s. 23. [Yanagiya S. Familiengeheime Eintich - Akupunktur.Ulm - Donau,1956-79 p.].

\section{Kodlubovskaya Tetiana}

Ph.D. (psychological sciences), associate professor, associate professor of the department of psychology, pedagogy, medical and pharmaceutical law of P. L. Shupyk National Medical Academy of Postgraduate Education, Kiev (Ukraine)

\section{MECHANISMS OF PSYCHO- PHYSIOLOGICAL METHODS OF REGU- LATION OF FUNCTIONAL STATES AMONG POLICE OFFICERS}

\section{ABSTRACT}

The article examines the results of the study of the effect of a complex of individually selected breathing techniques in conjunction with phytoarhomics and acupressure and mechanisms of their impact on the psychophysiological indicators of the functional conditions of police officers. In the group where the studies were carried out with the individual form of the classes, the number of people with signs of emotional tension, aggressiveness and anxiety decreased reliably. The indicators of the states increased: well-being, activity and mood. Confidence of the improvement 
in their indices of the reserves of the cardiovascular system and the adaptive potential was confirmed.

The results of the study convincingly state that the potential capabilities of individuallymatched respiratory techniques in combination with phytoharmaceuticals and acupressure in a short time (up to 10 minutes) allow normalizing psychophysiological potential and vegetative balance among police officers.

The obtained data testify to the important role of the training of police officers in the field of psychophysiological self-regulation of functional states after stress for their normalization and prevention of posttraumatic and psychosomatic disorders. The complex method of psychophysiological regulation (CMPR) of the functional states of police officers set forth in the article is based on the psychophysiological mechanisms of the individual personality approach (IPA), psychological and biological feedback (BOS). The technique of this method consists of the stages: express diagnosis (self-diagnosis), express - analysis (self-analysis) of information received about psycho-physiological indicators of functional states, individual selection of methods of regulation, performance of techniques regulation (selfregulation) and control diagnostics of psychophysiological indicators after applying a complex method of regulation.

The results of the use of CMPR are statistically reliable. The method has a number of patents and is confirmed by acts of implementation.
Key words: antistress respiratory fitoaroma regulation, acupressure, individual-personal approach, psychological and biological feedback, independent psychophysiological normalization of functional states.

\section{Кодлубівська Тетяна Борисівна}

Доцент, кандидат психологічних наук, доиент кафедри, психології, педагогіки, медичного $і$ фармацевтичного права, Начіональна медична академія післядипломної освіти імені П. Л. Шупика, м. Київ (Україна)

\section{МЕХАНІЗМИ ПСИХОФІЗІОЛОГІЧНИХ МЕТОДІВ РЕГУЛЮВАННЯ ФУНКЦІОНАЛЬНИХ СТАНІВ У СПІВРОБІТНИКІВ ПОЛІЦЇ̈}

Анотація. У статті розглянуті результати дослідження впливу комплексу індивідуально підібраних технік дихання спільно з фітоарома засобами, акупресурою і механізми їх впливу на психофізіологічні функціональні стану співробітників поліції. У групі, де проводилася дослідження при індивідуальній формі проведення занять, достовірно зменшилася кількість осіб, що мають ознаки емоційної напруги й агресивності і тривожності. Підвищилися показники станів: самопочуття, активності і настрою. Підтверджено достовірність поліпшення у них показників резервів серцево-судинної системи і адаптаційного потенціалу.

Результати дослідження переконливо констатують, що потенційні можливості індивідуально-підібраних дихальних технік в поєднанні з фітоарома засобами і акупрессурой- 
за короткий час (до 10 хвилин) дозволяють нормалізувати психофізіологічний потенціал $\mathrm{i}$ вегетативний баланс у співробітників поліції.

Отримані дані дослідження свідчать про важливу роль підготовки співробітників поліції в сфері психофізіологічної саморегуляції функціональних станів після стресу для їх нормалізації та профілактики посттравматичних і психосоматичних порушень. Викладений в статті комплексний метод психофізіологічної регуляції (КМПР) функціональних станів співробітників поліції заснований на психофізіологічні механізми індивідуального особистісного підходу (ИЛП), психологічної та білогічного зворотного ззку (БОС) .Технологія застосування даного методу складається з етапів: експрес-діагностики (самодіагностики), експрес-аналізу (самоаналізу) отриманої інформації про психофізіологічних показників функціональних станів, індивідуального підбору методів регуляції, виконання технік регуляції (саморегуляції) і контрольної діагностики психофізіологічних показників після їх застосування.

Результати застосування КМПР статистично достовірні. Метод має ряд патентів i підтверджений актами впровадження.

Ключові слова: антистресова дихальна фітоарома регуляція, акупресура, індивідуально-особистісний підхід, психологічна і біологічний зворотний зв'язок, самостійна психофі- зіологічна нормалізація функціональних станів. 